\title{
FAKTOR-FAKTOR YANG MEMPENGARUHI KECEMASAN IBU HAMIL PRIMIGRAVIDA TRISEMSTER III DALAM MENGHADAPI PERSALINAN DI PUSKESMAS BATU AJI KOTA BATAM TAHUN 2018
}

\author{
Yuditia Prameswari ${ }^{1}$, Zahra Ulfah $^{2}$ \\ ${ }^{1}$ Program Studi Psikologi, Fakultas Kedokteran dan Kesehatan Universitas Batam \\ yuditia.p@univbatam.ac.id
}

\begin{abstract}
The first pregnancy (primigravida) is a very important event for women because in addition to feeling happy and meaningful, it is also possible to feel anxiety and fear, when preparing for labour, especially entering the third trimester. Anxiety and fear can cause pain and can lead to decreased uterine contractions, so the labor process will last longer. The purpose of this study was to determine the factors that influencing the anxiety of Primigravida Trimester III pregnant women, in dealing with childbirth at the Batu Aji Health Center in Batam in 2018. This study was analytical with a cross sectional approach conducted in May - September 2018 at the Batu Aji City Health Center Batam. Data from the Batam City Health Office (Dinas Kesehatan Kota Batam) in 2017 shows that the highest coverage of pregnant women visits is in the Batu Aji Health Center with 4073 pregnant women. The sampling technique is total sampling with a sample size of 40 pregnant women. This study used the HRS-A questionnaire and checklist sheet. The researcher revealed that knowledge, occupational status, age were the factors to be studied. Data analysis using Chi-Square and the results obtained $p=0,000<0,05$, which indicates a significant correlation between the knowledge of pregnant women and anxiety of pregnant women, $\mathrm{p}=0,155<0,05$, no correlation between working status and the anxiety of pregnant women, $p=0.571 \geq 0.05$ and there is a correlation between the age of the mother and the anxiety of pregnant women, $\mathrm{p}=0.004<0.050$. There were 23 pregnant women who experienced low anxiety $(57.7 \%), 35$ people had good knowledge about pregnancy $(87.5 \%)$. Advice for health workers is to be able to improve the quality of care for pregnant women to reduce anxiety experienced by mothers, and pregnant women should use the health care facilities that have been provided..
\end{abstract}

Key Word : pregnancy, primigravida, anxiety

\begin{abstract}
ABSTRAK
Kehamilan pertama (primigravida) merupakan peristiwa yang sangat penting bagi wanita karena selain merasa bahagia dan bermakna, ada juga kemungkinan merasakan kecemasan dan ketakutan, saat mempersiapkan persalinan, terutama memasuki trimester ketiga. Kecemasan dan ketakutan dapat menyebabkan rasa sakit dan dapat menyebabkan penurunan kontraksi uterus, sehingga proses persalinan akan berlangsung lebih lama. Tujuan penelitian ini adalah untuk mengetahui faktor-faktor yang mempengaruhi kecemasan ibu hamil Primigravida Trimester III, dalam menangani persalinan di Puskesmas Batu Aji di Batam pada tahun 2018. Penelitian ini analitik dengan pendekatan cross sectional yang dilakukan pada bulan Mei - September. 2018 di Pusat Kesehatan Kota Batu Aji Batam. Data dari Dinas Kesehatan Kota Batam pada tahun 2017 menunjukkan bahwa cakupan kunjungan ibu hamil tertinggi adalah di Puskesmas Batu Aji dengan 4.073 perempuan hamil. Teknik pengambilan sampel adalah total sampling dengan jumlah sampel $40 \mathrm{ibu}$ hamil. Penelitian ini menggunakan kuesioner HRS-A dan lembar daftar periksa. Peneliti mengungkapkan bahwa pengetahuan, status pekerjaan, usia adalah faktor yang harus dipelajari. Analisis data menggunakan Chi-Square dan hasil yang diperoleh $p=0,000<0,05$, yang menunjukkan adanya korelasi yang signifikan antara pengetahuan ibu hamil dan kecemasan ibu hamil, $p=0,155$ $<0,05$, tidak ada korelasi antara status kerja dan kecemasan ibu hamil, $p=0,571 \geq 0,05$ dan ada hubungan antara usia ibu dan kecemasan ibu hamil, $p=0,004<0,050$. Ada 23 wanita hamil yang mengalami kecemasan rendah (57,7\%), 35 orang memiliki pengetahuan yang baik tentang kehamilan (87,5\%). Saran bagi petugas kesehatan adalah untuk dapat meningkatkan kualitas perawatan bagi ibu hamil untuk mengurangi kecemasan yang dialami ibu, dan ibu hamil harus menggunakan fasilitas perawatan kesehatan yang telah disediakan.
\end{abstract}

Kata kunci: kehamilan, primigravida, kecemasan

\section{PENDAHULUAN}

Proses kehamilan dan persalinan pada perempuan adalah salah satu proses yang paling berkesan sekaligus membuat khawatir. Beberapa macam perasaan seperti bahagia sekaligus cemas adalah persaan yang dianggap paling dominan dirasakan. Trimester akhir kehamilan atau trimester tiga sering disebut periode penantian dengan penuh kewaspadaan. Rasa cemas dan takut akan proses persalinan dan kelahiran meningkat sehingga harus dijelaskan tentang proses proses persalinan dan kelahiran yang 
sejelas- jelasnya agar timbul kepercayaan diri pada ibu bahwa ia dapat melalui proses persalinan dengan baik. Kecemasan pada ibu timbul akibat kurangnya pengetahuan dan ketidak-jelasan masalah yang dihadapinya (Wahyuningsih, 2015).

Kecemasan dan ketakutan dapat mengakibatkan rasa nyeri yang juga dapat mengakibatkan menurunnya kontraksi uterus, sehingga persalinan akan bertambah lama. Penelitian menunjukkan bahwa nyeri persalinan khususnya kala I lebih banyak dirasakan pada primigravida yaitu sebesar 59,38\% sedangkan pada multigravida sebesar 40,62\% (Difarissa, 2015). Kecemasan adalah hal yang normal bagi semua manusia, akan tetapi kecemasan menjadi tidak normal bila seseorang menanggapi kecemasan secara unrealistic / berlebihan dan mengakibatkan gangguan fisik, psiskis, dan sosial. Cemas adalah suatu emosi yang sejak dulu dihubungkan dengan kehamilan, yang hubungan ini tidak jelas. Cemas mungkin emosi positif sebagai perlindungan menghadapi stresor, yang bisa menjadi masalah apabila berlebihan (Pieter, dkk, 2011). Kecemasan merupakan bagian dari respon emosional, proses yang terjadi adalah kekhawatiran yang tidak jelas sumbernya, yang berkaitan dengan perasaan yang tidak pasti dan tidak berdaya. Seorang individu yang mengalami kecemasan secara langsung dapat mengekspresikan kecemasan melalui respon fisiologis dan perilaku (Stuart, 2006). Kecemasan tersebut bisa dialami oleh ibu dalam masa kehamilan, terutama pada kehamilan trimester akhir menjelang persalinan (Wahyuningsih,2015). Kekhawatiran yang dirasakan oleh wanita hamil pada trimester pertama, kedua, dan ketiga memiliki ciri- ciri tersendiri sesuai dengan masalah pada kehamilannya (Sulistiowati, 2013).

Peneliti melakukan penelitian di Puskesmas Batu Aji karena berdasarkan data dari Dinas Kesehatan Kota Batam tahun 2017, jumlah cakupan kunjungan ibu hamil terbanyak yaitu di Puskesmas Batu Aji dengan jumlah 4073 ibu hamil. (Profil Kesehatan Kota Batam, 2017). Penelitian ini dilakukan dengan metode analitik dengan pendekatan cross sectional, yaitu mengetahui faktor usia, pendidikan, pekerjaan dan pengetahuan ibu hamil yang berhubungan dengan kecemasan ibu hamil dalam menghadapi persalinan. Penelitian ini dilakukan di Puskesmas Batu Aji yang dilakukan pada bulan Mei - September 2018. Populasi penelitian ini adalah seluruh ibu hamil primigravida trimester III yang datang untuk memeriksakan kehamilannya di Puskesmas Batu Aji.

\section{TINJAUAN LITERATUR}

\subsection{Kecemasan}

\subsubsection{Pengertian Kecemasan}

Kecemasan merupakan suatu perasaan subjektif mengenai ketegangan mental yang menggelisahkan sebagai reaksi umum dari ketidak mampuan mengatasi suatu masalah atau tidak adanya rasa aman. Perasaan yang tidak menentu tersebut pada umumnya tidak menyenangkan yang nantinya akan menimbulkan atau disertai perubahan fisiologis dan psikologis (Rochman, 2010). Kecemasan adalah sesuatu yang menimpa hampir setiap orang pada waktu tertentu dalam kehidupannya. Kecemasan merupakan reaksi normal terhadap situasi yang sangat menekan kehidupan seseorang. Kecemasan bisa muncul sendiri atau bergabung dengan gejala-gejala lain dari berbagai gangguan emosi (Rumaiah, 2003).

Menurut Kelly, kecemasan adalah mengenali bahwa situasi peristiwa yang di hadapi oleh seseorang berada di luar jangkauan kenyamanan pada system konstruk seseorang (Cervone, 2012).Berdasarkan dari beberapa ahli, maka dapat di simpulkan bahwa kecemasan adalah keadaan yang menimpa hampir setiap orang yang memiliki perasaan tidak nyaman dan perasaan merasa tidak mampu menghadapi peristiwa atau situasi yang sedang di alaminya.

\subsubsection{Jenis- Jenis Kecemasan}

Menurut Kaplan dan Sadock (dalam Susilowati, 2012) kecemasan di bagi menjadi dua jenis yaitu

\section{a. Kecemasan Normal}

Kecemasan adalah suatu penyerta yang normal dari pertumbuhan, dari perubahan, dari pengalaman, sesuatu yang baru dan belum di coba dan penemuan identitasnya sendiri dan arti hidup

\section{b. Kecemasan Patologi}

Kecemasan patologi adalah respon yang tidak sesuai terhadap stimulus yang diberikan berdasarkan intensitas dan durasinya

\subsubsection{Tingkat Kecemasan}

Stuart (2007) membagi tingkat kecemasan menjadi empat tingkat antara lain :

1) Kecemasan ringan 
Berhubungan dengan ketegangan dalam kehidupan seharihari. Kekecewaan ini menyebabkan individu menjadi waspada dan meningkatkan lapang persepsinya. Kecemasan ini dapat memotivasi belajar dan menghasilkan pertumbuhan serta kreatifitas.

2) Kecemasan sedang

Memungkinkan individu untuk berfokus pada hal yang penting dan mengesampingkan yang lain. Kecemasan ini mempersempit lapang persepsi individu dengan demikian individu tidak mengalami perhatian yang selektif namun dapat berfokus pada lebih banyak area jika diarahkan untuk melakukannya.

3) Kecemasan berat

Sangat mempengaruhi lapang persepsi individu. Individu cenderung berfokus pada suatu yang rinci dan spesifik serta tidak berfikir pada hal lain. Semua perilaku ditujukan untuk mengurangi ketegangan. Individu tersebut memerlukan banyak arahan untuk berfokus pada area lain.

4) Tingkat panik

Ketakutan yang berhubungan dengan terperangah, takut, dan teror. Hal yang rinci terhadap proposinya karena mengalami hilang kendali, individu yang mengalami panik tidak mampu melakukan sesuatu walaupun dengan arahan. Panik merupakan disorganisasi dan menimbulkan peningkatan aktifitas motorik, menurunnya kemampuan untuk berhubungan dengan orang lain, persepsi yang menyimpan dan kehilangan pemikiran yang rasional, tingkat kecemasan ini tidak sejalan dengan kehidupan, jika berlangsung terus dalam waktu yang lama, dapat terjadi kelelahan dan kematian.

\subsubsection{Faktor-Faktor Yang Mempengaruhi Kecemasan}

a. Faktor predisposisi

Beberapa faktor yang dapat mempengaruhi terjadinya kecemasan (Stuart, 2007). Faktor faktor tersebut antara lain :

1). Teori psikoanalitik

Menurut teori psikoanalitik Sigmund Freud, kecemasan timbul karena konflik antara elemen kepribadian yaitu id(insting) dan super ego (nurani ). Id mewakili dorongan insting dan impuls primitif seseorang sedang superego mencerminkan hati nurani seseorang dan dikendalikan norma budayanya. Ego berfungsi menengahi tuntutan dari dua elememen yang bertentangan dan fungsi kecemasan adalah mengingatkan ego bahwa ada bahaya.

2). Teori interpersonal

Menurut teori ini kecemasan timbul dari perasan takut terhadap tidak adanya penerimaan dan penolakan interpersonal. Kecemasan Juga berhubungan dengan perpisahan dan kehilangan yang menimbulkan kelemahan spesifik.

3). Teori behavior

Kecemasan merupakan produk frustrasi yaitu segala sesuatu yang mengganggu kemampuan seseorang untuk mencapai tujuan yang diinginkan.

4). Teori perspektif keluarga

Kecemasan dapat timbul karena pola interaksi yang tidak adaptif dalam keluarga

5). Teori perspektif biologi

Fungsi biologis menunjukkan bahwa otak mengandung reseptor khusus Benzodiapine. Reseptor ini mungkin membantu mengatur kecemasan. Penghambat asam amino butirikgamma neuro regulator (GABA) juga mungkin memainkan peran utama dalam mekanisme biologis berhubungan dengan kecemasan sebagaimana endomorfin. Selain itu telah dibuktikan bahwa kesehatan umum seseorang mempunyai akibat nyata sebagai predisposisi terhadap kecemasan. Kecemasan dapat disertai gangguan fisik dan menurunkan kapasitas seseorang untuk mengatasi stressor.

b. Faktor presipitasi

Faktor presipitasi adalah faktor-faktor yang dapat menjadi pencetus terjadinya kecemasan (Stuart, 2007). Faktor pencetus tersebut adalah :

1) Ancaman terhadap integritas seseorang yang meliputi ketidakmampuan fisiologis atau menurunnya kemampuan untuk melakukan aktivitas hidup sehari-hari.

2) Ancaman terhadap sistem diri seseorang dapat membahayakan identitas harga diri dan fungsi sosial yang terintegrasi dari seseorang. Pada pasien yang akan menjalani operasi 


\subsubsection{Respon Kecemasan}

faktor pencetus kecemasannya adalah faktor yang dialami individu baik bersifat internal maupun eksternal. Faktor internalnya adalah adanya ketakutan akan pembiusan,kecacatan, kematian, takut akan rasa nyeri, takut kehilangan pekerjaan, menjadi tanggungan keluarga. Sedangkan faktor eksternalnya adalah lingkungan yang baru,peralatan operasi atau pembiusan yang asing serta petugas kesehatannya.

Kecemasan dapat mempengaruhi kondisi tubuh seseorang, respon kecemasan menurut Suliswati (2005) antara lain:

a. Respon Fisiologis terhadap Kecemasan

Secara fisiologis respon tubuh terhadap kecemasan adalah dengan mengaktifkan sistem saraf otonom (simpatis maupun parasimpatis). Sistem saraf simpatis akan mengaktivasi proses tubuh, sedangkan sistem saraf parasimpatis akan meminimalkan respon tubuh. Reaksi tubuh terhadap kecemasan adalah "fight" atau "flight". Flight merupakan reaksi isotonik tubuh untuk melarikan diri, dimana terjadi peningkatan sekresi adrenalin ke dalam sirkulasi darah yang akan menyebabkan meningkatnya denyut jantung dan tekanan darah sistolik, sedangkan fight merupakan reaksi agresif untuk menyerang yang akan menyebabkan sekresi noradrenalin, rennin angiotensin sehingga tekanan darah meningkat baik sistolik maupun diastolik. Bila korteks otak menerima rangsang akan dikirim melalui saraf simpatis ke kelenjar adrenal yang akan melepaskan adrenalin atau epinefrin sehingga efeknya antara lain napas menjadi lebih dalam, nadi meningkat. Darah akan tercurah terutama ke jantung, susunan saraf pusat dan otot. Dengan peningkatan glikogenolisis maka gula darah akan meningkat.

b. Respon Psikologis terhadap Kecemasan

Kecemasan dapat mempengaruhi aspek interpersonal maupun personal. Kecemasan tinggi akan mempengaruhi koordinasi dan gerak refleks. Kesulitan mendengarkan akan mengganggu hubungan dengan orang lain. Kecemasan dapat membuat individu menarik diri dan menurunkan keterlibatan dengan orang lain.

c. Respon Kognitif

Kecemasan dapat mempengaruhi kemampuan berpikir baik proses pikir maupun isi pikir, diantaranya adalah tidak mampu memperhatikan, konsentrasi menurun, mudah lupa, menurunnya lapang persepsi, dan bingung.

d. Respon Afektif

Secara afektif klien akan mengekspresikan dalam bentuk kebingungan dan curiga berlebihan sebagai reaksi emosi terhadap kecemasan.

\subsection{Kehamilan}

\subsubsection{Pengertian Kehamilan}

Kehamilan adalah fertilisasi atau penyatuan spermatozoa dan ovum kemudian dilanjutkan dengan implantasi atau nidasi. Kehamilan normal akan berlangsung selama 40 minggu atau 9 bulan menurut kalender internasional jika dihitung dari fertilisasi sampai bayi lahir. Kehamilan dibagi menjadi 3 trimester yaitu trimester pertama mulai 0- 12 minggu, trimester kedua 13-27 minggu, dan trimester ketiga 28-40 minggu (Saifuddin, 2014).

\subsubsection{Paritas}

Paritas adalah jumlah janin dengan berat badan lebih dari atau sama dengan 500 gram yang pernah dilahirkan, hidup maupun mati. Bila berat badan tak diketahui maka dipakai umur kehamilan, yaitu 24 minggu (Siswosudarmo, 2008). Penggolongan paritas bagi ibu yang masih hamil atau pernah hamil berdasarkan jumlahnya.

Menurut Perdinakes-WHOJPHIEGO yaitu:

a. $\quad$ Primigravida adalah wanita hamil untuk pertama kalinya

b. Multigravida adalah wanita yang pernah hamil beberapa kali, di mana kehamilan tersebut tidak lebih dari 5 kali.

c. Grandemultigravida adalah wanita yang pernah hamil lebih dari 5 kali. 


\subsection{3}

\section{Ibu Hamil Trimester III}

Kehamilan trimester III adalah kehamilan dengan usia 27 - 40 minggu, masa ini merupakan suatu yang lebih berorientasi pada realitas untuk menjadi orang tua yang menanti kelahiran anak dimana ikatan antara orang tua dan janin yang berkembang pada trimester ini (Mochtar, 2002).

Perubahan Fisik dan Psikologis pada Trimester III menurut Kurnia (2009) adalah sebagai berikut :

a. $\quad$ Sakit bagian tubuh belakang

Sakit pada bagian tubuh belakang (punggung-pinggang), karena meningkatnya beban berat dari bayi dalam kandungan yang dapat memengaruhi postur tubuh sehingga menyebabkan tekanan ke arah tulang belakang.

b. Konstipasi

Pada trimester ini sering terjadi konstipasi karena tekanan rahim yang membesar kearah usus selain perubahan hormon progesteron.

c. Pernafasan

Karena adanya perubahan hormonal yang mempengaruhi aliran darah ke paru-paru, pada kehamilan 33-36 minggu, banyak ibu hamil akan merasa susah bernapas. Ini juga didukung oleh adanya tekanan rahim yang membesar yang berada di bawah diafragma (yang membatasi perut dan dada).

d. Sering buang air kecil

Pembesaran rahim ketika kepala bayi turun ke rongga panggul akan makin menekan kandung kencing ibu hamil.

e. Varises

Peningkatan volume darah dan alirannya selama kehamilan akan menekan daerah panggul dan vena di kaki, yang mengakibatkan vena menonjol, dan dapat juga terjadi di daerah vulva dan vagina. Pada akhir kehamilan, kepala bayi juga akan menekan vena daerah panggul yang akan memperburuk varises. Varises juga dipengaruhi faktor keturunan

f. Kontraksi perut

Braxton-Hicks atau kontraksi palsu ini berupa rasa sakit di bagian perut yang ringan, tidak teratur, dan akan hilang bila ibu hamil duduk atau istirahat.

g. Bengkak

Perut dan bayi yang kian membesar selama kehamilan akan meningkatkan tekanan pada daerah kaki dan pergelangan kaki ibu hamil, dan kadang membuat tangan membengkak. Ini disebut edema, yang disebabkan oleh perubahan hormonal yang menyebabkan retensi cairan.

h. Kram pada kaki

Kram kaki ini timbul karena sirkulasi darah yang menurun, atau karena kekurangan kalsium

\subsection{Faktor- faktor yang Mempengaruhi Kecemasan Ibu Hamil Dalam Menghadapi} Persalinan

Menurut (Trsetiyaningsih, 2011 dan Jannah, 2012:141-143) mengemukakan bahwa terdapat

faktor - faktor yang berpengaruh terhadap kecemasan ibu hamil yaitu :

a. Stressor internal

Merupakan stressor yang berasal dari dalam diri ibu sendiri. Adanya beban psikologis yang ditanggung ibu dapat menyebabkan gangguan perkembangan bayi dalam kandungan. Stressor internal meliputi kecemasan yang dialami dalam diri ibu hamil tersebut, misalnya kurang percaya diri, perubahan penampilan, perubahan peran sebagai orang tua, sikap ibu terhadap kehamilan, persalinan, dan kehilangan pekerjaan.

b. Stressor eksternal

Merupakan pemicu stres yang berasal dari luar diri ibu, seperti: status sosial, relationship, kasih sayang, support mental, broken home, dan respon negatif dari lingkungan.

c. Dukungan keluarga

Pada setiap tahap usia kehamilan, ibu akan mengalami perubahan baik fisik maupun psikologis. Ibu harus melakukan adaptasi pada setiap perubahan yang terjadi. Ibu hamil sangat membutuhkan dukungan yang intensif dari keluarga dengan cara menunjukkan perhatian dan kasih sayang. 


\section{METODOLOGI}

\subsection{Desain Penelitian}

Rancangan dalam penelitian ini adalah cross sectional yaitu untuk mengetahui FaktorFaktor yang Mempengaruhi Kecemasan Ibu Hamil Primigravida Trimester III Dalam Menghadapi Persalinan di Puskesmas Batu Aji Kota Batam Tahun 2018.

\subsection{Waktu dan Tempat Penelitian}

\subsubsection{Waktu}

Penelitian ini di laksanakan pada bulan Mei - September 2018

\subsubsection{Tempat Penelitian}

Penelitian di laksanakan di Puskesmas Batu Aji.

\subsection{Populasi dan Sampel}

\subsubsection{Populasi}

Populasi dalam penelitian ini adalah seluruh ibu hamil primigravida trimester III yang berkunjung dan melakukan pemeriksaan pada bulan Mei - September di Puskesmas Batu Aji sebanyak 40 ibu hamil

\subsubsection{Sampel}

Teknik pengambilan sampel dari penelitian ini menggunakan total sampling.

\subsection{Instrumen Penelitian}

Instrumen dalam penelitian ini menggunakan lembar kuesioner dan check list. Untuk mengukur tingkat kecemasan menggunakan Hamilton Rating Scale for Anxiety (HRS-A). Untuk mengetahui tingkat kecemasan pada ibu hamil dalam menghadapi persalinan digunakan skala likert yang terdiri dari komponen pada pertanyaan negatif Hampir tidak pernah nilai skornya 1, Kadang-kadang nilai skornya 2, Sering nilai skornya 3, Selalu nilai skornya 4. Pada komponen pertanyaan negatif maka skor pada penilaian hamper tidak pernah (HTP) 4, Kadang Kadang (K) 3, Sering (SR) 2, Selalu (SL) 1. Dilakukan penentuan panjang kelas berdasarkan rumus statistik, maka untuk mengkategorikan tingkat kecemasan ibu hamil dalam menghadapi persalinan maka dikatakan tingkat kecemasan ringan 20-35, tingkat kecemasan sedang 35-50, tingkat kecemasan berat 5165, dan panik 66- 80.

\subsection{Pengumpulan Data}

Data yang di kumpulkan adalah data primer yang di peroleh langsung dari responden dan jawaban atas pertanyaan yang disediakan melalui pengisian kuesioner.

\section{HASIL DAN PEMBAHASAN}

\subsection{Hasil Analisa Univariat}

Tabel 4.1 Distribusi Frekuensi Kejadian Kecemasan Ibu Hamil Primigravida Trimester III Dalam Menghadapi Persalinan di Puskesmas Batu Aji Kota Batam Tahun 2018

\begin{tabular}{ccc}
\hline Tingkat Kecemasan & N & Persentase (\%) \\
\hline Kecemasan Ringan & 23 & 57,7 \\
Kecemasan Sedang & 13 & 32,5 \\
Kecemasan Berat & 4 & 10 \\
Panik & 0 & 0 \\
\hline Jumlah & $\mathbf{4 0}$ & $\mathbf{1 0 0}$ \\
\hline
\end{tabular}

Tabel 4.2 Distribusi Frekuensi Pengetahuan Ibu Hamil Primigravida Timester III Dalam Menghadapi Persalinan di Puskesmas Batu Aji Kota Batam Tahun 2018

\begin{tabular}{ccc}
\hline Pengetahuan & N & Persentase $(\boldsymbol{\%})$ \\
\hline Baik & 35 & 87,5 \\
Kurang & 5 & 12,5
\end{tabular}




$\begin{array}{lll}\text { Jumlah } & 40 & 100\end{array}$

Tabel 4.3 Distribusi Frekuensi Pendidikan Ibu Hamil Primigravida Timester III Dalam Menghadapi Persalinan di Puskesmas Batu Aji Kota Batam Tahun 2018

\begin{tabular}{ccc}
\hline Pendidikan & N & Persentase (\%) \\
\hline Pendidikan Tinggi & 4 & 10 \\
Pendidikan Menengah & 36 & 90 \\
Pendidikan Rendah & 0 & 0 \\
\hline Jumlah & $\mathbf{4 0}$ & $\mathbf{1 0 0}$ \\
\hline
\end{tabular}

Tabel 4.4 Distribusi Frekuensi Pekerjaan Ibu Hamil Primigravida Timester III Dalam Menghadapi Persalinan di Puskesmas Batu Aji Kota Batam Tahun 2018

\begin{tabular}{ccc}
\hline Pekerjaan & N & Persentase (\%) \\
\hline Bekerja & 8 & 20 \\
Tidak Bekerja & 32 & 80 \\
\hline Jumlah & $\mathbf{4 0}$ & $\mathbf{1 0 0}$ \\
\hline
\end{tabular}

Tabel 4.5 Distribusi Frekuensi Usia Ibu Hamil Primigravida Timester III Dalam Menghadapi Persalinan di Puskesmas Batu Aji Kota Batam Tahun 2018

\begin{tabular}{ccc}
\hline Usia & N & Persentase (\%) \\
\hline Reproduksi & 28 & 70 \\
Non Reproduksi & 12 & 30 \\
\hline Jumlah & $\mathbf{4 0}$ & $\mathbf{1 0 0}$ \\
\hline
\end{tabular}

\subsubsection{Hasil Analisa Bivariat}

Tabel 4.6 Hubungan Pengetahuan Dengan Kecemasan Ibu Hamil Primigravida Trimester III di Puskesmas Batu Aji Kota Batam 2018

\begin{tabular}{|c|c|c|c|c|c|c|c|}
\hline \multirow{2}{*}{ Kecemasan Ibu Hamil } & \multicolumn{4}{|c|}{ Pengetahuan Ibu Hamil } & \multicolumn{2}{|c|}{ Total } & \multirow{2}{*}{$\boldsymbol{p}$ - Value } \\
\cline { 2 - 7 } & $\mathbf{3}$ & $\mathbf{\%}$ & $\mathbf{N}$ & $\mathbf{\%}$ & $\mathbf{N}$ & $\mathbf{\%}$ & \\
\hline Kecemasan Ringan & 23 & 100 & 0 & 0 & 23 & 100 & \\
\hline \multirow{2}{*}{ Kecemasan Sedanng } & 11 & 84,6 & 2 & 15,4 & 13 & 100 & \multirow{2}{*}{$\mathbf{0 , 0 0 0}$} \\
\hline Kecemasan Berat & 1 & 25 & 3 & 75 & 4 & 100 & \\
\hline Jumlah & $\mathbf{3 5}$ & & $\mathbf{5}$ & & $\mathbf{4 0}$ & & \\
\hline
\end{tabular}

Tabel 4.7 Hubungan Pendidikan Dengan Kecemasan Ibu Hamil Primigravida Trimester III di Puskesmas Batu Aji Kota Batam 2018

\begin{tabular}{|c|c|c|c|c|c|c|c|}
\hline \multirow{3}{*}{$\begin{array}{c}\text { Kecemasan Ibu } \\
\text { Hamil }\end{array}$} & \multicolumn{4}{|c|}{ Pendidikan Ibu Hamil } & \multirow{2}{*}{\multicolumn{2}{|c|}{ Total }} & \multirow{3}{*}{$p$-Value } \\
\hline & \multicolumn{2}{|c|}{$\begin{array}{c}\text { Pendidikan } \\
\text { Tinggi }\end{array}$} & \multicolumn{2}{|c|}{$\begin{array}{c}\text { Pendidikan } \\
\text { Menengah }\end{array}$} & & & \\
\hline & $\mathbf{N}$ & $\%$ & $\mathbf{N}$ & $\%$ & $\mathbf{N}$ & $\%$ & \\
\hline Kecemasan Ringan & 1 & 4,3 & 22 & 95,7 & 23 & 100 & \\
\hline Kecemasan Sedanng & 3 & 23,1 & 10 & 76,9 & 13 & 100 & \\
\hline
\end{tabular}




\begin{tabular}{|c|c|c|c|c|c|c|c|}
\hline Kecemasan Berat & 0 & 0 & 4 & 100 & 4 & 100 & \\
\cline { 1 - 3 } & $\mathbf{4}$ & & $\mathbf{3 6}$ & & $\mathbf{4 0}$ & & \\
\hline
\end{tabular}

Tabel 4.8 Hubungan Pekerjaan Dengan Kecemasan Ibu Hamil Primigravida Trimester III dengan di Puskesmas Batu Aji Kota Batam 2018

\begin{tabular}{|c|c|c|c|c|c|c|c|}
\hline \multirow{3}{*}{$\begin{array}{c}\text { Kecemasan Ibu } \\
\text { Hamil }\end{array}$} & \multicolumn{4}{|c|}{ Pekerjaan Ibu Hamil } & \multirow{2}{*}{\multicolumn{2}{|c|}{ Total }} & \multirow{3}{*}{$p$-Value } \\
\hline & \multicolumn{2}{|c|}{ Bekerja } & \multicolumn{2}{|c|}{ Tidak Bekerja } & & & \\
\hline & $\mathrm{N}$ & $\%$ & $\mathrm{~N}$ & $\%$ & $\mathrm{~N}$ & $\%$ & \\
\hline $\begin{array}{c}\text { Kecemasan } \\
\text { Ringan }\end{array}$ & 5 & 21,7 & 18 & 78,3 & 23 & 100 & \\
\hline $\begin{array}{l}\text { Kecemasan } \\
\text { Sedanng }\end{array}$ & 3 & 23,1 & 10 & 76,9 & 13 & 100 & 0,571 \\
\hline Kecemasan Berat & 0 & 0 & 4 & 100 & 4 & 100 & \\
\hline Jumlah & 8 & & 32 & & 40 & & \\
\hline
\end{tabular}

Tabel 4.9 Hubungan Usia Dengan Kecemasan Ibu Hamil Primigravida Trimester III di Puskesmas Batu Aji Kota Batam 2018

\begin{tabular}{|c|c|c|c|c|c|c|c|}
\hline \multirow{3}{*}{ Kecemasan Ibu Hamil } & \multicolumn{4}{|c|}{ Usia Ibu Hamil } & \multirow{2}{*}{\multicolumn{2}{|c|}{ Total }} & \multirow{3}{*}{$p$-Value } \\
\hline & \multicolumn{2}{|c|}{ Reproduksi } & \multicolumn{2}{|c|}{ Non Reproduksi } & & & \\
\hline & $\mathrm{N}$ & $\%$ & $\mathrm{~N}$ & $\%$ & $\mathrm{~N}$ & $\%$ & \\
\hline Kecemasan Ringan & 19 & 82,6 & 4 & 17,4 & 23 & 100 & \\
\hline Kecemasan Sedanng & 9 & 69,2 & 4 & 33,3 & 13 & 100 & 0,004 \\
\hline Kecemasan Berat & 0 & 0 & 4 & 10 & 4 & 100 & \\
\hline Jumlah & 28 & & 12 & & 40 & & \\
\hline
\end{tabular}

\section{KESIMPULAN}

Berdasarkan penelitian yang telah di lakukan di Poli Puskesmas Batu Aji, dapat di simpulkan sebagai berikut,

a. Kecemasan yang di alami ibu hamil primigravida trimester III di Puskesmas Batu Aji adalah 23 orang $(57,5 \%)$ ibu mengalami kecemasan ringan, 12 orang $(32,5 \%)$ ibu mengalami kecemasan sedang, 4 orang (10\%) ibu mengalami kecemasan berat.

b. Pengetahuan ibu hamil primigravida trimester III di Puskesmas Batu Aji adalah 35 orang $(87,5 \%)$ ibu dengan pengetahuan baik, 5 orang $(12,5 \%)$ ibu mengalami pengetahuan kurang

c. Pendidikan ibu hamil primigravida trimester III di Puskesmas Batu Aji adalah 36 orang (90\%) ibu berpendidikan menengah, 4 orang (10\%) ibu berpendidikan tinggi

d. Pekerjaan ibu hamil primigravida trimester III di Puskesmas Batu Aji adalah 32 orang (80\%) ibu tidak bekerja, 8 orang (20\%) ibu bekerja

e. Usia ibu hamil primigravida trimester III di puskesmas Batu Aji adalah 28 orang $(70 \%)$ ibu dengan usia reproduksi, 12 orang (30\%) ibu dengan usia non reproduksi.

f. Ada hubungan yang signifikan antara pengetahuan dengan kecemasan ibu hamil primigravida timester III di Puskesmas Batu Aji Kota Batam 2018 (p-value 0,000 < $0,05)$ 
g. Tidak ada hubungan yang signifikan antara pendidikan dengan kecemasan ibu hamil primigravida timester III di Puskesmas Batu Aji Kota Batam 2018 (p-vallue 0,155 $\geq$ $0,05)$.

h. Tidak ada hubungan yang signifikan antara pekerjaan dengan kecemasan ibu hamil

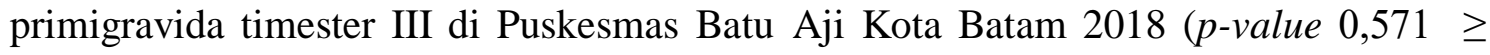
$0,05)$

i. Ada hubungan yang signifikan antara usia dengan kecemasan ibu hamil primigravida timester III di Puskesmas Batu Aji Kota Batam 2018 ( p-value 0,000 <0,05)

\section{Referensi}

AKI.2015.http://storage.jak-stik.ac.id/ProdukHukum/MenPAN/index.php-

option $=$ com_docman\&task=doc_download\&gid=290\&Itemid $=111$.pdf diakses Pada tanggal 10 April 2018

Aprillia, Y. 2011. Pentingnya Pendamping Persalinan. Jakarta: PT Gramedia Widia Sarana Indonesia

Carroli, G., Mignini, L. (2012). "Episiotomy For Vaginal Birth". http://www.thecochranelibrary.com

Cunningham, F.G., Leveno, K.J., Bloom, S.L., Hauth, J.C., Gilstrap, L., Wenstrom, K.D. (2005). "Williams Obstetrics 22ND Edition". United States of America : McGraw-Hill

Depkes. 2017. http://www.depkes.go.id/article/view/17081700004/-inilah-capaian-kinerja-kemenkes-ritahun-2015--2017.html diakses Pada tanggal 10 April 2018

Decherney, A.H., Nathan L., Goodwin T.M., Laufer, N. (2007). "Current Diagnosis and Treatment Obstetrics and Gynecology". United States of America : McGraw-Hill

Handayani, Reska. 2012. Faktor-Faktor Yang Berhubungan Dengan Tingkat Kecemasan Menjelang Persalinan Pada Ibu Primigravida Trimester III di Wilayah Kerja Puskesmas Lubuk Buaya Padang Tahun 2012. STIKes Amanah Padang.

Hawari, Dadang. 2011. Manajemen Stress Cemas Dan Depresi. Jakarta : FKUI.

Jannah,Nurul. 2012. Buku Ajar Asuhan Kebidanan :kehamilan. Yogyakarta: CV Andi OF SET

Manuaba, Ida Bagus Gede. 2010. Ilmu Kebidanan, Penyakit Kandungan, KB untuk Pendidikan Bidan. Jakarta: EGC

Mochtar, R. 2002. Sinopsis Obstetri. Jakarta: Buku Kedokteran EGC Jakarta.

Notoadmodjo, S. 2011. Metodelogi Penelitian Kesehatan. Jakarta: Rineka Cipta

Notoatmodjo, 2010. Metodologi Penelitian Kesehatan. Jakarta; PT Rineka Cipta

Notoatmodjo, Soekidjo., 2010. Promosi Kesehatan : Teori dan Aplikasi. Jakarta : Rineka Cipta

Rosa, Yunilda. 2015. Hubungan Karakteristik Dengan Tingkat Kecemasan Ibu Trimester III Dalam Menghadapi Persalinan Di Rumah Bersalin Citra Palembang Tahun 2015. STIK Siti Khadijah palembang.

Rumaiah, S. (2003). Kecemasan Bagaimana Mengatasi Penyebabnya. Jakarta: Pustaka Populer Obor.

Sagita, Yona Desni. 2017. Hubungan Tingkat Kecemasan Dengan Lama Persalinan Kala II Pada Ibu Bersalin Di RSIA Anugerah Medical Center Kota Metro. STIkes Aisyah Pringsewu Lampung

Saifuddin, Abdul B. 2014. Buku Acuan Nasional Pelayanan Kesehatan Maternal dan Neonatal, Jakarta: Yayasan Bina Pustaka Sarwono Prawirohardjo.

Shodiqoh, dkk. 2014. Perbedaan Tingkat Kecemasan Dalam Menghadapi Persalinan Antara Primigravida dan Multigravida. Surabaya : FKM UA

Simanjuntak, Lasma. 2012. Tingkat Kecemasan Dan Koping Ibu Hamil yang Berlatar Belakang Pendidikan Medis Dan Non Medisdalam Menghadapi Persalinandi Kota Pematang Sianta. Universitas Sumatra Utara : Medan

Siswosudarmo, R., 2008. Obstetri Fisiologi. Yogyakarta: Pustaka Cendekia.

Stuart, G., W. 2007. Buku Saku Keperawatan Jiwa (Edisi 5). Jakarta : EGC

Sulistyawati, Ari. 2010. Asuhan Kebidanan Pada Masa Kehamilan. Jogjakarta : CV. Andi Offset.

Suliswati et al. 2005. Konsep Dasar Keperawatan Kesehatan Jiwa. Jakarta : EGC.

Sumarah. 2009. Perawatan Ibu Bersalin : asuhan Kebidanan pada Ibu Bersalin. Yogyakarta

Susilowati, Dewi. 2012. Pengaruh Dukungan Keluarga Dan Paritas Terhadap Kecemasan Ibu Hamil Trimester III Dalam Menghadapi Persalinan Di RB Harapan Bunda Surakarta. Universitas Sebelas Maret : Surakarta 
Wahyuningsih, Istiqomah Risa. 2015. Faktor-Faktor Yang Berhubungan Dengan Tingkat Kecemasan Ibu Dalam Menghadapi Persalinan Di Rb Hasanah Gemolong Sragen. Sekolah Tinggi Ilmu Kesehatan Aisyiyah Surakarta.

Winknjosastro, H., 2002. Ilmu Kebidanan. Jakarta: Yayasan Bina Pustaka Sarwono Prawirohardjo 